\title{
Working in Cooperatives and Social Economy: Effects on Job Satisfaction and the Meaning of Work
}

Travailler en coopérative et dans l'économie sociale, effets sur la satisfaction et le sens du travail

Trabajar en cooperativa y en la economía social, efectos sobre la satisfacción y el sentido del trabajo

Davy Castel, Claude Lemoine and Annick Durand-Delvigne

\section{(2) OpenEdition}

Electronic version

URL: http://journals.openedition.org/pistes/2635

DOI: $10.4000 /$ pistes.2635

ISSN: 1481-9384

Publisher

Les Amis de PISTES

Printed version

Date of publication: 1 November 2011

\section{Electronic reference}

Davy Castel, Claude Lemoine and Annick Durand-Delvigne, « Working in Cooperatives and Social Economy: Effects on Job Satisfaction and the Meaning of Work », Perspectives interdisciplinaires sur le travail et la santé [Online], 13-2 | 2011, Online since 01 November 2011, connection on 02 May 2019. URL : http://journals.openedition.org/pistes/2635 ; DOI : 10.4000/pistes.2635

This text was automatically generated on 2 May 2019.

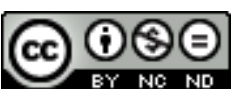

Pistes est mis à disposition selon les termes de la licence Creative Commons Attribution - Pas d'Utilisation Commerciale - Pas de Modification 4.0 International. 


\section{Working in Cooperatives and Social Economy: Effects on Job Satisfaction and the Meaning of Work}

Travailler en coopérative et dans l'économie sociale, effets sur la satisfaction et le sens du travail

Trabajar en cooperativa y en la economía social, efectos sobre la satisfacción y el sentido del trabajo

Davy Castel, Claude Lemoine and Annick Durand-Delvigne

\section{INTRODUCTION}

1 According to its representatives (SCOP network representing cooperative and participative companies in France) and the specialized press (Participer; Alternatives économiques), cooperative management is assumed to increase the quality of life at work and workers' job satisfaction. A few years after the foundation in France of the Supreme Council of the Social Solidarity Economy (July 11, 2006), which is in charge of promoting this economic sector, it seems appropriate to investigate the effects of the social economy approach on quality of life at work and especially on workers' job satisfaction. Indeed, quality of life at work and job satisfaction in the social economy sector have not been the focus of many studies until now, in particular in the French context. In this study conducted in France, we carried out a qualitative analysis of the links between social economy characteristics and job satisfaction. Our analysis will help to determine if social economy represents an organizational model that can be a source of job satisfaction, and if so, to identify factors that explain this positive impact in order to encourage their development in all work organizations. 


\subsection{JOB SATISFACTION}

2 Job satisfaction corresponds to one's attitude about work and work environment (Weiss, 2002), and depends on the fit between the work characteristics perceived by the individual and his expectations (Bretz \& Judge, 1994; Dawis, 1992; Kristof-Brown, Zimmerman \& Johnson, 2005). Since the two-factors theory (Herzberg, 1966, 1978) was developed, two categories of determinants affecting job satisfaction and dissatisfaction have been discerned. Intrinsic factors correspond to the work activity characteristics while extrinsic factors correspond to the work environment characteristics. The intrinsic factors are the following: occupational accomplishment, recognition, work interest, responsibilities, promotion, task identification, autonomy, work usefulness, task diversity, self-efficacy in work, and skills use. As for the extrinsic factors, they are: company rules, management skills, income, working conditions, work schedules, employment stability, safety at work, workload, relationships with coworkers and management, status, role, and job prestige (Herzberg, 1978; Johnson \& Johnson, 2002; Ritter \& Anker, 2002; Souza-Pouza \& Souza-Pouza, 2000; Spector, 1997). Job satisfaction has important implications for several variables. It may decrease intentions to leave the company (Tett \& Meyer, 1993), absenteeism and burnout (Vandenberghe, Stordeur \& D 'Hoore, 2009), and increase work performance (Iaffaldano \& Muchinsky, 1985) and organizational commitment (Van Knippenberg \& Van Schie, 2000). Job satisfaction is also a significant predictor of the overall level of happiness (Argyle, 2001). In a study conducted by the polling institute Ipsos in November 2009 and commissioned by the Centre d'Analyse Stratégique - an organization working under the direction of the Prime Minister, who is in charge of helping the government define and implement its economic, social, environmental, and cultural policies - $99 \%$ of respondents declared that « enjoying their work » was a main factor in good mental health. Indeed, it was the most frequently cited determinant. A high level of job satisfaction is a necessary condition for an optimal state of health, which is characterized by the balance between requirements and contributions of individuals and their environment (definition provided by the Canadian Ministry of Health, 1988). Improving job satisfaction is therefore a major issue which is highlighted by the fact that, in the current climate of our highly competitive economy, companies seem to require more and more commitment and self-efficacy from employees. The denial of dissatisfaction and the absence of solutions in such a context may lead both to counter-productivity and suffering. Public authorities seem to be more and more aware of the problem, as demonstrated by the fact that increasing job satisfaction is the first in a series of objectives adopted by EU leaders at the Lisbon (2000) and Laeken (2001) summits in order to increase the quality of life at work.

\subsection{THE SOCIAL ECONOMY SECTOR}

Social economy organizations develop economic activity based on the following four principles (Defourny, 1992): social aims rather than profit maximization; organizational autonomy; democratic decision-making within the organization; priority of people and labour over capital in surplus distribution. Toward the end of 2006, social economy represented $10 \%$ of the GDP, $9 \%$ of the companies and $10 \%$ of the jobs $(2.1$ million of workers) in France (National Council of Regional Chambers of Social Economy, 2009). In this country, social economy includes associations, mutual insurance companies, and 
cooperatives. Associations constitute the largest part of the social economy sector and alone represent $85 \%$ of the organizations and $80 \%$ of the jobs in the sector (1.7 million workers). They differ from the two other types of organizations because voluntary members in associations usually outnumber wage-earning members. The economic dimension of the activity is often lower than in mutual insurance companies and workerowned cooperatives. Profits cannot moreover be redistributed to members in associations, unlike mutual insurance and worker-owned cooperatives which, while their primary objective is not profit, are not required to comply with the non-distribution constraint. Mutual insurance companies are in charge of the collective risk management of their insured parties. They differ from private insurance companies in that they are controlled by their members (the insured people themselves or their representatives). Mutual insurance companies employ 118,000 people in France, which accounts for $6 \%$ of social economy jobs (NCRCSE, op.cit.). Concerning cooperatives, three categories must be distinguished: worker-owned cooperatives («SCOP» in France), consumer or user cooperatives, and business cooperatives (which bring together managers, tradesmen, or craftsmen who pool resources to secure business and financing).

Not all social economy organizations are work organizations per se. Most associations and consumer cooperatives do not fit into this category for one of two reasons: first, they do not develop economic activity even though they are considered to be part of the social economy, and second, they do not represent the main work activity of their volunteers and part-time workers. These types of organizations are therefore not relevant as a field of research on job satisfaction in the social economy sector. In business cooperatives, companies work together but the cooperative status may have a neutral impact on the forms of work organization within each company. Therefore, only mutual insurance companies, cooperative banks and worker-owned cooperatives can be seen as relevant places for studying the effects of social economy on job satisfaction. However, since their members are first and foremost their clients - and not their employees - mutual insurance companies and cooperative banks can apply social economy practices without significant consequences for their workers. Worker-owned cooperatives are therefore the organization in the social economy sector where participative management is likely to have the greatest influence on the workers' quality of life at work. We therefore decided to select worker-owned cooperatives as the most relevant type of organization in which to study the effects of social economy on job satisfaction. This means that if social economy characteristics have a positive or negative effect on job satisfaction, it is in worker-owned cooperatives that they are most likely to be observed. It also means that the results observed in worker-owned cooperatives should not be unhesitatingly generalized to the whole social economy sector.

\subsection{WORKER-OWNED COOPERATIVES (W.o.c.)}

Worker-owned cooperatives develop a cooperative management style to reduce the gap between conception and execution based on the worker-associate principle: workers are not only the employees of the organization but also the main owners and take part in all strategic and operative decisions. The International Cooperative Alliance (ICA) defines a cooperative as « an autonomous association of persons voluntarily united to meet their common economic, social, and cultural needs and aspirations through a jointly owned and democratically controlled enterprise ». As social economy organizations, the aim of 
worker-owned cooperatives is not only economic growth but also social usefulness, responsibility, and contribution to the socioeconomic development of their community. Economic surpluses are assigned in priority to develop work activity and jobs and not to maximize profits for stockholders. In their relations with their economic environment, worker-owned cooperatives aim to preserve independence and their members' freedom of decision and to be subject as little as possible to free market rules (even if legally they have to comply with the same economic rules as other companies). Cooperatives are owned by their employees who therefore have to make an individual contribution to its capital by becoming associates (all workers are not necessarily associates even if all are expected to become so; in some cooperatives, it is compulsory after two years of employment). Cooperatives are democratically supervised according to the principle "one person-one vote". Based on this vote, equality between members replaces inequality based on hierarchical status. The manager(s) of the company is(are) chosen from the associates-workers and elected by them. Rules inside the company are based on collective deliberation and voluntary adhesion more than on submission to an authority. Finally, information is expected to be shared between all members and not to be only in the hands of the management.

6 In France, in 2009, there were 1,925 worker-owned cooperatives (1,600 en 2005) corresponding to 3.9 billion Euros in sales and 40,425 jobs (35,000 in 2005 and 28,000 in 1998). The average size of a worker-owned cooperative is 21 workers but this average hides substantial variations, as $60 \%$ of the cooperatives are small companies with less than 9 employees. Worker-owned cooperatives are well represented in the tertiary sector (46\% of the cooperatives in France), industry (23.5\%), and the building sector (29\%). Building and intellectual services (consulting, engineering) are the two main job-creating sectors. On average, $67.5 \%$ of workers are associates and $80 \%$ will become associates after two years in the company. Women account for $60 \%$ of workers in cooperatives, which is similar to the other organizations of the social economy sector and contrary to the private sector, where the proportion of men and women is reversed. However, as in the private sector and contrary to the other social economy organizations, men represent $75 \%$ of cooperative managers and executives. The distribution of social and occupational groups in cooperatives indicates an atypical job structure with only a few employees and a very large proportion of white collar jobs (close to $40 \%$ ). The proportion of workers over $50(30 \%)$ is slightly higher in worker-owned cooperatives than in the private sector and similar to the public sector. A large proportion of cooperative jobs are full-time jobs (more than $80 \%$ ), which is a major difference with the other social economy organizations, especially associations (CNCRES, 2009; Réseau SCOP Entreprises, 2010).

\subsection{W.O.C AND JOB SATISFACTION}

7 We assume that, for most intrinsic factors, job satisfaction is high in worker-owned cooperatives and that social economy principles are a source of job satisfaction. Reducing the gap between the conception and execution of tasks, increasing task significance, developing workers' skills, seeking to benefit the global environment and society while involving everyone in decision-making should increase job satisfaction upon completing the activity. Job satisfaction is also assumed to be high for many extrinsic factors in cooperatives: a higher level of shared business culture, increased confidence in elected management, greater attention to working and employment conditions following the 
increased social responsibility of the company, and collective decision-making. However, the relation between working in cooperatives and job satisfaction is assumed to be much more complex with regard to several aspects. The perceived pressure may be weak and cause less dissatisfaction because of the large number of resources (autonomy, initiatives) but the growing responsibilities of the associates-workers also increase the demands of activities. Similarly, interpersonal relationships may be improved due to greater equality between workers but can also worsen because of role ambiguity (e.g., being an employee and employer at the same time) and because of a higher likelihood of conflict resulting from the increased weight of each employee.

\section{RESEARCH METHODOLOgY}

\subsection{SAMPLE}

8 We studied job satisfaction in two companies; the first one was a worker-owned cooperative and the second, a private company, this being, as much as possible, the only major difference. They were therefore chosen from the same sector: consulting and communication in sustainable development. Intellectual services is the largest of the activity sectors in which worker-owned cooperatives are well represented in France, representing 33\% of the cooperatives in France (Réseau SCOP Entreprises, 2010). Consulting and communication companies create the majority of new jobs in intellectual services, with an employment growth of 8.5\% per year between 2001 and 2006. Moreover, a significant proportion of the cooperatives in this activity sector are located in the North of France where the study took place. However, this area of activity is also that in which small-sized cooperatives represent the biggest proportion, with $82 \%$ of companies having less than 9 employees and an average size of only 15 workers, compared to 21 on average in all sectors (CNCRES, 2009; Réseau SCOP Entreprises, 2010).

In our efforts to find two companies within this sector, we first tried to find a workerowned cooperative and then to identify a private company as similar as possible to the former regarding criteria such as company size and the main work activity. With this in mind, we made an initial selection among the cooperatives in this economic sector based on two criteria: the size of the company, selecting only companies with 5 or more workers, many of them having less; and its location, that is accessible to the interviewer. Then selected cooperatives were contacted by e-mail and asked to participate in the study. After having identified a cooperative, we contacted private companies in the same field and of the same size. A private company quite similar to the cooperative, including location and operating range, was selected.

The selected cooperative, created in 1993, employed seven workers (one administrative assistant, five consultants, one of whom was the managing director, and one project assistant). It specialized in leading sustainable development projects. There were seven participants from the cooperative, namely five women and two men between 24 and 47 years old, the average being 32. Education varied from vocational diplomas to Ph.D.s; seniority in the company varied from three months to four years, the average being two years. None of the employees had worked in a cooperative before joining this one and only a few of them had experience in consulting and communication. Five of the seven workers were associates; two could become associates as soon as they met the required six months of seniority. Six jobs were full-time and one was part-time. 
11 The selected private company was a consulting agency in public communication created in 1990 and specializing in project-leading linked to decentralization and sustainable urban development. It employed six people: the agency's creator and director, one creative director, two consultants, one project-leader and one assistant. One of the consultants was absent (holidays) and did not participate in the study. There were five participants from the private company, three women and two men between 27 and 45 years of age, the average being 38. Education varied from a French baccalaureate (highschool diploma) to a Master's degree; seniority in the company varied from seven months to 17 years, the average being 7.25 years. All employees had past experience in their work field, the average being 12.4 years. The agency director and the creative director were the shareholders in the company. All the jobs were full-time.

12 The two companies did not differ in size and activity sector. A difference emerged concerning occupations, since the cooperative was almost exclusively composed of consultants while the private company had various occupational statuses. However, this difference was a direct consequence of the choice of the cooperative not to introduce a hierarchy as in private companies. The other difference concerned seniority in the company and past professional experience. Difference in seniority and experience levels may lead people to express different aspirations, and therefore different job satisfaction levels, and is likely to have consequences on work organization. These differences represent important factors that must be considered when examining results. Other demographic variables did not show sizeable differences between the two selected companies.

\subsection{ASSESSMENT TOOLS}

13 We conducted a qualitative analysis of job satisfaction using semi-structured interviews. We were thus able to accurately analyze the explanatory factors of expressed satisfactions and dissatisfactions as well as to identify the role of social economy characteristics. Interviews were constructed around two questions: "What are the main causes of satisfaction in your current job and why?" and "What are the main causes of dissatisfaction in your current job and why?" Interviews lasted between 30 and 45 minutes and participants were not interrupted; the interviews stopped when interviewees considered that they had completely answered the two questions. Each interviewee was allowed to mention as many factors as he or she wanted to. Interviews were recorded and then submitted to a thematic content analysis based on the agreement between three examiners. The aim was to identify satisfaction and dissatisfaction factors present in what the participants said as well as the role of the social economy characteristics. The frequency of occurrence and the order of apparition were used as indicators of each factor's importance. Participants were also asked to give an evaluation of their global level of satisfaction or dissatisfaction on a 1-100 scale (instructions were provided on how to use the scale).

\subsection{PROCEDURE}

Interviews were conducted with employees based on a voluntary participation. We tried to increase the participants' involvement by introducing the study as an opportunity to discuss and diagnosis and not as a risk or constraint associated with the disclosure of 
personal information. Participants were informed beforehand that the interviews dealt with job satisfaction / dissatisfaction factors. However, so as not to influence the participants' answers, there was never any mention, either before or during the interviews, of our hypotheses concerning the influence of social economy. Data collection took place in the two companies in a one-month interval. Interviews were conducted during working days in a quiet environment and in the absence of any other people. Because of unavailability, only six of the seven employees of the cooperative participated in the interviews.

\section{RESULTS}

\subsection{INTERVIEWS ANALYSIS}

\subsubsection{SATISFACTIONS AND DISSATISFACTIONS IN THE COOPERATIVE}

first job satisfaction factor, expressed by all those taking part in the cooperative (6/6), was the cohesion of the work team. For these employees, cohesion meant a high degree of perceived proximity between the workers and a high level of convergence in goals and values. The cohesion of the work team was not, according to the participants, a consequence of collegiality but rather a consequence of age proximity and common experience between workers. According to the participants the inverse relation was true: collegiality was a consequence of the work team's cohesiveness. The relation between cohesion and collegiality is discussed in the last part of this paper.

Working in a cooperative was the second main satisfaction factor. It was declared by five of the six participants (5/6) for the following reasons: the high level of autonomy and responsibility and, above all, the same level of responsibility for everyone; the promotion of collaboration instead of competition; a collective management which "made the coelaboration real", gave an important role to each employee and made the integration of staff easier; the high consideration for the role and contribution of each employee, presented as exceptional by those who had worked previously in a private company; the equality of the statuses; the "humanized" wage policy (people perceived that their interests were given priority).

The third satisfaction factor (3/6) was the work activity itself (interest, usefulness, and diversity). The activity sector (sustainable development) played an important role in the perceived interest and usefulness of the tasks. The work activity itself was judged meaningful because the company took its social and economic responsibilities seriously and because activities were conducted in accordance with the social economy principles.

The first factor of dissatisfaction in the cooperative, reported by four of the six respondents (4/6), was running public meetings, which was an important part of their work. In one case, this function itself was dissatisfactory: the respondent had a positive attitude toward the function (relevance and usefulness) but felt uncomfortable doing it. In the other three cases, the staggered hours and the long travel distances to hold these public meetings (which take place in the evening) were the source of dissatisfaction. That led to a spillover of work into family and private life, particularly prominent here as the cooperative was predominantly composed of women and as work-life conflict is still mainly a female issue (Durand-Delvigne, Verquerre \& Masclet, 2000). 

Cohesion appeared to be uneven and encroaching. It was uneven because the long-term employees inevitably formed a core that new staff had to integrate. It was encroaching because, according to the workers, the cohesion led the work team to act like it was professionally "cut off from the world", since the cooperative systematically worked with companies that shared social economy values, but also personally, since their daily behaviors and relationships were also influenced by the professional values that they supported.

The third factor of dissatisfaction (2/6) concerned task division within the work team. Consultants had to spend time on administrative tasks regarded as secondary despite the presence of an administrative assistant. It was creating conflicts and misunderstanding within the work team: on the one hand, the consultants considered that administrative tasks should have been the administrative assistant's responsibility and, on the other hand, the assistant considered that the consultants were not aware of the extent of the workload involved.

The last factor of dissatisfaction (2/6) was pay, since wages did not correspond to the employees' qualifications. Respondents considered, when comparing themselves with workers from private companies, that they had to choose (when they decided to work in a cooperative) between work interest and incomes. They declared that they did not regret this choice and therefore did not consider income to be a priority. Moreover, according to them, the control they had over wage policies and decisions decreased their dissatisfaction because it was their choice not to increase their wages in order to preserve the cooperative's sustainability.

\subsubsection{SATISFACTIONS AND DISSATISFACTIONS IN THE PRIVATE COMPANY}

Within the private company, the company's values were the main satisfaction factor according to all participants (5/5). The company's culture was based on three important values: freedom of choice, complementarity, and honesty.

Freedom of choice corresponded to the freedom that the company took in selecting projects on the basis of other criteria than return. In this way, workers identified possibilities for increasing a project's meaning. This freedom, according to the participants, differentiated this company from other private companies. The application of freedom within the company in terms of work autonomy and self-regulation instead of external control was also a source of satisfaction.

Complementarity corresponded to the interdisciplinarity implemented in this agency: Workers came from various educational fields and the organization of the activity was based on their respective expertise. According to the workers, this way of working was satisfactory since it was a source of personal enrichment and work efficiency.

Honesty corresponded to the willingness to be honest in communications and to give priority to the truth over profitability. It consisted in making technical experts and communication specialists work together in order to report the actual virtues of projects without hiding their inconveniences. This way of working increased the interest, usefulness, and efficiency of the work because it was, according to the workers, the most valid one in the long run. Honesty was a value directly linked to their field of work (i.e., public action, sustainable development) because, according to the respondents, it would be harder to give it greater priority than profits in other work fields.

Perspectives interdisciplinaires sur le travail et la santé, 13-2 | 2011 
The second satisfaction factor in the private company arose directly from honesty as a value and from the priority given to the meaning of work over profitability, namely work usefulness, which was declared by four of the five participants (4/5). They considered that their activity was a response to existing needs in the society.

The third satisfaction factor was confidence in the management based on the transparency of the agency director's decisions, who informed workers of the direction she wanted to give to the company's activity, direction with which the employees totally agreed. Consequently, both the company's aims and the fact that they were clearly communicated were satisfactory.

Though the company's values are the main satisfaction factor in the private company, it also generated new demands and drawbacks that constituted the main dissatisfaction factor (3/5). First, difficulties arose from the fact that these professional values were new and rare. Indeed, the position involving commitment to sincerity and honesty is marginal in communication practices. It was accordingly more demanding for workers who needed to communicate the relevance of such positioning. Whereas the cornerstone of the company's activity was to get technical experts and communication specialists working together, it was hampered by the fact that this coordination was new and complicated. Expressing the company values in work activity therefore had a flip side: it led to insecurity and stress. Or, as one participant put it, "freedom is insecurity". However, according to respondents, the satisfactions that arose from these company values were considerably greater than the dissatisfactions. Nonetheless, complementarity was a company value that involved certain drawbacks for the work team. Considering the size of the company, the fact that each worker was the single representative of his or her profession tended to isolate everyone. The negative consequences of the company's values were the only dissatisfaction factor in the private company that was declared by at least two persons.

Table 1 summarizes the main satisfaction and dissatisfaction factors in both companies

\begin{tabular}{|l|l|l|}
\hline & Worker-Owned Cooperative & Private company \\
\hline \multirow{5}{*}{ Satisfactions } & $\begin{array}{l}\text {-Work team cohesion (6/6) } \\
\text {-Working in a cooperative } \\
(5 / 6) \\
\text {-Work interest, usefulness, } \\
\text { and diversity (3/6) }\end{array}$ & $\begin{array}{l}\text {-Company values: honesty, complementarity, } \\
\text { freedom (5/5) } \\
\text {-Work usefulness (4/5) }\end{array}$ \\
\hline Dissatisfactions & $\begin{array}{l}\text {-Staggence in the management (3/5) } \\
\text { family-work conflict (4/6) } \\
\text {-Unequal and encroaching } \\
\text { team cohesion (2/6) } \\
\text {-Task division (2/6) } \\
\text {-Income (2/6) }\end{array}$ & $\begin{array}{l}\text {-Demands and drawbacks of company values } \\
(3 / 5): \text { novelty, complexity, and isolation }\end{array}$ \\
\hline
\end{tabular}




\subsection{ANALYSIS OF THE SELF-REPORTED SATISFACTION SCORES}

28 We also asked participants to declare their global level of satisfaction or dissatisfaction on a scale ranging from 1 (complete dissatisfaction) to 100 (complete satisfaction). In the worker-owned cooperative, satisfaction levels varied from 70 to 90/100. In the private company, satisfaction levels varied from 45 to $90 / 100$. One respondent declared a satisfaction score of 45/100 whereas those of the others varied from 80 to 90 . Job satisfaction was high in the cooperative as well as in the private company, except for one person who declared herself rather dissatisfied. During the interview, this respondent indicated "substantial" dissatisfactions which were not raised by the other workers in the private company, namely low income and the under-utilization of the person's qualifications and skills. This respondent held a position at the bottom of the company's hierarchy and considered that the other workers did not give her enough room to fulfill herself in her activities.

\section{DISCUSSION}

\subsection{THE SOCIAL ECONOMY PRINCIPLES ARE A SOURCE OF JOB SATISFACTION}

Our hypothesis was that the goals and organizational model of the social economy approach would be a source of job satisfaction for two reasons. First, we assumed that social economy principles - by reducing the gap between the conception and execution of tasks and by allowing workers to control the work process - would have a positive impact on intrinsic job satisfaction by increasing the work's interest, the workers' autonomy and responsibilities, and the proper use of workers' skills. Second, collegial governance was assumed to increase job satisfaction related to the work team, the modalities of work organization, and the company values because of better work team cohesion, greater cooperation, and work meaning that was in accordance with the company's triple responsibility (economic, social, and environmental). Information extracted from the interviews confirmed that the purposes and patterns of work organization promoted by the social economy sector were sources of job satisfaction. The cohesion of the work team, the specific features of the worker-owned cooperative (shared responsibility, collegial governance, equality between workers, consideration for others) and the relevance and usefulness of the work were the three main satisfaction factors for the cooperative's workers. The cooperative was perceived as a source of responsibility, cooperation, autonomy, consideration, equality, and collective governance. Work usefulness - as important as work interest in job satisfaction according to the respondents - was described by the employees as the consequence of social economy's strengths, namely that the company places its social and environmental responsibilities at the same level as its economic ones.

Like De Cooman, De Gieter, Pepermans \& Jegers (2011), we came to the overall conclusion that workers from non-profit organizations attach a great deal of value to the social usefulness of their activity and have a high intrinsic motivation. Indeed, the job satisfaction factors ensuing from the implementation in cooperatives of the social economy sector's governing principles correspond to the same job characteristics that 
self-determination theory identifies as increasing satisfaction by meeting an individual's needs for autonomy, competency, and relatedness (Gagné \& Forest, 2009): participation in decision-making, control of the purposes and processes of work, cooperation and knowledge-sharing. These autonomy-supportive forms of motivation have positive consequences for individuals as well as for organizations (Gagné \& Forest, op.cit.; Vallerand, 1997). «Autonomy-supportive (rather than controlling) work environments and managerial methods promote basic need satisfaction, intrinsic motivation, and full internalization of extrinsic motivation, and these in turn lead to persistence, effective performance, job satisfaction, positive work attitudes, organizational commitment, and psychological well-being " (Gagné \& Deci, 2005, p. 346).

\subsection{SOCIAL ECONOMY PRINCIPLES ARE NOT THE EXCLUSIVE PROPERTY OF W.O.C}

31 While the cooperative's employees highlighted work usefulness, company values and human consideration, that was also the case for the employees in the private company. Indeed, the company values and the work usefulness were their two main satisfaction factors. A close look at the values which provided satisfaction revealed that two of the three main values were principles promoted by the social economy sector that the private company also chose to implement. The first of these values was called «freedom of choice » by participants and corresponded both to the subordination of profit to other more relevant (according to the work team) criteria in the decision-making process (a principle promoted by the social economy sector) and to freedom-supportive managerial methods within the company. The second value was named "honesty" by the participants and corresponded to the prioritization of social responsibility and usefulness over other criteria such as profitability in the aims and practices of the company (in this respect, it was closer to the social economy sector than to the private sector). Two of the main satisfaction factors in the private company corresponded precisely to the characteristics of worker-owned cooperatives: the prioritization of the meaning and usefulness of the work over profit, autonomy-supportive management, and a high degree of consideration for people. Thus, the four social economy founding principles - which were defined notably by Defourny (1992) and which were assumed to differentiate social economy from market economy and cooperatives from private companies - were in great part applied in both of the studied companies, even though the hierarchical structure of the private company did not indicate this. Referring to the Quinn model of organizational styles (Quinn, 1988) and to the FOCUS research group (Muijen, Van Koopman, Dondeyne, De Cock \& De Witte, 1992; Lemoine, 1998), the private company described here had the characteristics of the "innovative start-up » described by Fraccola \& Lemoine (2008). It was characterized by autonomy-supportive managerial methods. Hierarchical relations were direct and personalized and priority was given to promote positive relationships. Workers had a high level of autonomy and personal initiatives were encouraged. The company's objectives could be easily appropriated by employees. These characteristics distinguished this private company from other private companies and moved it closer to social economy companies, especially cooperatives. That was probably the reason why self-reported satisfaction levels did not differ greatly between the two groups. We expected that the social economy principles would express themselves through the cooperative structure, whereas they were predominantly revealed through the company values and the goals assigned to work. Being organized in a cooperative, belonging to the 
social economy sector, and "officially " adopting its principles were not the sole conditions for the social economy principles to influence managerial methods and therefore job satisfaction.

In summary, the examination of the semi-structured interviews revealed that social economy goals and the meaning they gave to work were sources of job satisfaction. They appeared amongst the main satisfaction factors in the two companies, and when they gave rise to dissatisfactions, the latter were consistently described as secondary when compared with the satisfactions resulting from the same factors. The purposes and meaning of work conveyed through company values appeared to be more influential on managerial methods and individuals' attitudes and feelings than the work setting and the formal work structure itself. As declared by an employee of the cooperative: "What matters is the purpose, not the structure.» Because the work goals defined by the organization corresponded to the orientation the individuals wanted to give to their work activity, they were able to find meaning in what they did, which is an essential source of job motivation and satisfaction (Morin, 1996). The study likewise clearly showed that the perceived social usefulness and relevance of the work played a central role in the development of its meaning (Morin, op.cit.).

\subsection{IMPLEMENTING SOCIAL ECONOMY SECTOR PRINCIPLES DID NOT ONLY HAVE POSITIVE CONSEQUENCES}

Without undermining our former conclusions, these results also indicated that implementing social economy sector principles did not only have positive consequences on employees' job satisfaction. While the implementation of these governance principles was at the source of several kinds of job satisfaction in the two companies, it almost systematically had drawbacks, namely isolation, marginalization, and increased demands. In this respect, it was noteworthy that the same factors led to both satisfactions and dissatisfactions. This observation goes against Herzberg's two-factor theory $(1966,1978)$, which postulated that intrinsic factors are a source of satisfaction whereas extrinsic factors are a source of dissatisfaction. More generally, it calls into question the unequivocal characteristic of job satisfaction factors which are assumed to be either satisfactory or dissatisfactory according to most of the job satisfaction assessment tools based on questionnaires. These results reveal in fact the "polydoxical " nature of attitudes (Bely, Lemoine \& Germain, 1997).

\subsection{DID COOPERATIVE ORgANIZATION HAVE A SPECIfIC INFLUENCE ON JOB SATISFACTION?}

Did cooperative management have its own consequences, ones that did not result strictly from implementing social economy principles and that could not be conveyed only by the company's values and goals? Collegial governance was indeed an important source of job satisfaction within the cooperative studied here. However, does collegial governance necessarily involve job satisfaction and efficient functioning? Is it applicable to and applied in all worker-owned cooperatives? The analysis of the interviews conducted with the cooperative's workers yielded some answers that will need to be further examined in future research. Respondents who worked both in private and cooperative companies claimed that work team cohesiveness was extremely important in determining whether 
or not collegial governance was a source of satisfaction or dissatisfaction, efficiency or inefficiency. Work team cohesion - corresponding here to the perceived degree of proximity between members and to the level of convergence in aims and values - was perceived by the respondents as a condition rather than as a consequence of collective governance. According to them, collegial governance can only be efficient if the work team cohesion is sufficiently strong to ensure that people consider themselves to be equal members of the team. For example, the cooperative employees explained that the collective governance of the cooperative was only effective after its creator left the company. Despite the fact that the company had been a cooperative since its creation, the presence of its creator in the work team led the other employees to follow the "mentor, " and therefore restricted the effective collective governance despite the company's official status as a worker-owned cooperative. When the work team was not cohesive and homogenous, collegial governance could not really be implemented, even if it was the official company status. The feeling of equality between workers, based on the feeling that the contribution of each person is equivalent, would thus seem to be the cornerstone of a well-adapted collective governance within a work team. Individuals will use elements such as age or professional experience in order to evaluate to what extent their contribution is comparable to other peoples' contributions. If they come to the conclusion that they are making an equal contribution to the company, they will probably ask the work organization to reflect this equality by giving everyone the same status and responsibilities. But if workers do not feel equal because they consider their contribution to be unequal, they will probably not expect a collective management to erase these differences that "in fact" exist (at least in the evaluation process of individuals). Equality between workers cannot be proclaimed, it must find its legitimacy in the homogeneity of the work team. Only then can the collective governance formalize and reinforce the existing feelings of equality between workers. Conversely, if workers consider that each worker makes an equal contribution to the company and if this feeling is not reinforced by a collective management but instead foiled by a hierarchical structure, then dissatisfaction is likely to increase. Neither collective management nor hierarchical work settings are assumed to be in themselves a source of satisfaction. The success, in terms of employee satisfaction, of one or the other management structures depends on its adaptation to the characteristics of the work team. Eventually, the two dimensions are likely to reinforce each other. If work team cohesion is a condition for collective governance, collective governance also leads to the reinforcement of work team cohesion, especially through recruitment practices: cooperatives are likely to seek collaborators that in addition to their skills are motivated to support the company's values.

\subsection{CONCLUSIONS}

35 In conclusion, this study has attempted to show that the principles promoted by social economy organizations and especially by worker-owned cooperatives had a positive effect on workers' job satisfaction. This positive effect lied in workers' adherence to these principles, regardless of whether they were entitled «social economy» or not: social usefulness and sustainability rather than profits, autonomy inside and outside the company, democratic decision-making, and a reduction in the gap between the conception and execution of tasks. Moreover, the impact of these principles on work characteristics and therefore on individuals' attitudes toward work was conveyed by 
work goals and company's values and was not directly dependent on the adoption of a cooperative form of enterprise. In other words, the results of the present research tend to demonstrate that though the adoption and implementation by most companies of social economy values and goals would undoubtedly be an initiator of job satisfaction - in particular because of the development of work interest and meaning - the adoption of a collective governance must depend on the characteristics of the work team.

We would like to thank the employees of the two companies for their participation in the study and Eleanor Moody and Jacqueline Hamrit for their advice on this paper. We also thank Elise Ledoux, Richard Whelan and the two anonymous reviewers for their contribution to the improvement of this article.

\section{BIBLIOGRAPHY}

Alternatives économiques. (2006). L'économie sociale de A à Z. Guide pratique d'Alternatives économiques, 22 (janvier).

Argyle, M. (2001). The Psychology of Happiness ( $\left.2^{\text {nd }} e d.\right)$. London: Routledge.

Belly, B., Lemoine, C. et Germain, R. (1997). La polydoxie concernant l'autorité : multiplicité d'opinions en fonction de la méthode de leur recueil. Psychologie du travail et des organisations, 3 , 1-2, 20-31.

Bretz, R. D. et Judge, T. A. (1994). Person-organization fit and the theory of work adjustment: Implications for satisfaction, tenure, and career success. Journal of Vocational Behavior, 44(1), 32-54. Centre d'analyse stratégique (2009). La santé mentale, l'affaire de tous. Pour une approche cohérente de la qualité de vie. Rapport du Centre d'analyse stratégique, 115 (nov.) www.strategie.gouv.fr

CNCRES (2009). Atlas de l'économie sociale et solidaire 2009. http://www.rtes.fr/IMG/pdf/ AtlasESSFranceRegionsCNCRES.pdf

Dawis, R. V. (1992). Person-environment fit and job satisfaction. In C. J. Cranny, P. C. Smith et E. F. Stone (Eds.), Job satisfaction: How people feel about their jobs and how it affects their performance. New York: Lexington Books.

De Cooman, R., De Gieter, S., Pepermans, R. et Jegers, M. (2011). A cross-sector comparison of motivation related concepts in for profit and not for profit service organizations. Nonprofit and Voluntary Sector Quarterly.40(2), 296-317.

Defourny, J. (1992). L'émergence du secteur d'économie sociale en Wallonie. Coopératives et développement, 23(1), 151-175.

Durand-Delvigne, A., Verquerre, R. et Masclet, G. (2000). L'aménagement et la réduction du temps de travail : quels effets sur la qualité de vie ? Psychologie du travail et des organisations, 6(1-2), 107-119.

Fraccola, R. et Lemoine, C. (2008). Start-up innovantes : conséquences de l'évolution organisationnelle sur la culture des salariés et le climat de travail. In C. Lemoine, A. Balikdjian, N. 
Kridis et $\mathrm{P}$. Salengro (Eds.), Organisation, engagement et équipes de travail. Actes du XIVe Congrès de l'AIPTLF, tome 5 (p.88-99). Lille : Éditions de l'AIPTLF (CD-ROM).

Gagné, M. et Deci, E. L. (2005). Self-determination theory and work motivation. Journal of Organizational Behavior, 26, 331-362.

Gagné, M. et Forest, J. (2009). La motivation au travail selon la théorie de l'autodétermination, vol. 3. In P. Roussel, J. Rojot et C. Vandenberghe (Eds.), Comportement organisationnel (p. 215-234). Bruxelles : Éditions De Boeck.

Herzberg, F. (1966). Le travail et la nature de l'homme. 4 e édition en 1978. Paris : Entreprise Moderne d'Édition.

Iaffaldano, M. T. et Muchinsky, P. M. (1985). Job satisfaction and job performance: A metaanalysis. Psychological Bulletin, 97(2), 251-273.

Johnson, G. et Johnson, W. (2002). Perceived over-qualification and dimensions of job satisfaction: A longitudinal analysis. Journal of Psychology, 134, 537-555.

Kristof-Brown, A. L., Zimmerman, R. D. et Johnson, E. C. (2005). Consequences of individuals' fit at work: A meta-analysis of person-job, person-organization, person-group, and person-supervisor fit. Personnel Psychology, 58, 281-342.

Lemoine, C. (1998). Style d'organisation et mode d'évaluation. In M. Rousson et L. ThygesenFischer (Eds.), Psychologie du travail et transformations de la société (p. 99-107). Neuchâtel : Presses Académiques de Neuchâtel.

Lemoine, C. (2007). De la question à l'autoquestionnement : questionner, source d'emprise et d'appropriation multiple. Psychologie du travail et des organisations, $13, n^{\circ} 4$, p. 5-24.

Morin, E. M. (1996). Psychologies au travail. Montréal : Gaétan Morin Éd.

Muijen, J. J. Van, Koopman, P., Dondeyne, P., De Cock, G. et De Witte, K. (1992). Organizational culture, the development of an international instrument for comparing countries. Proceedings $2^{\text {nd }}$ congress of psychology. Budapest.

Quinn, R. (1988). Beyond rational management. San Francisco : Jossey-Bass.

Réseau SCOP entreprises (2010). Chiffres des SCOP.

http://www.les-scop.coop/sites/fr (date de consultation : 6/08/10).

Ritter, A. J. et Anker, R. (2002). Bons emplois, mauvais emplois : les jugements des travailleurs dans cinq pays. Revue internationale du travail, 141(4), 331-358.

Souza-Pouza, Al. et Souza-Pouza, An. (2000). Well-being at work: A cross-national analysis of the levels and determinants of job satisfaction. Journal of Socio-Economics, 29, 517-538.

Spector, P. E. (1997). Job satisfaction: Application, assessment causes and consequences. London: Sage.

Tett, R. P. et Meyer, J. P. (1993). Job satisfaction, organizational commitment, turnover intention, and turnover: Path analyses based on meta-analytic findings. Personnel Psychology, 46(2), 259-293.

Vallerand, R. J. (1997). Toward a hierarchical model of intrinsic and extrinsic motivation. In M. P. Zanna (Ed.), Advances in experimental social psychology (vol. 29, p. 271-360). San Diego, CA: Academic Press.

Vandenberghe, C., Stordeur, S. et D'Hoore, W. (2009). Une analyse des effets de la latitude de décision, de l'épuisement émotionnel et de la satisfaction au travail sur l'absentéisme au sein des unités de soins infirmiers. Le travail humain, 72(3), 209-228. 
Van Knippenberg, D. et Van Schie, C. M. (2000). Foci and correlates of organizational identification. Journal of Occupational and Organizational Psychology, 73(2), 137-147.

Weiss, H. M. (2002). Deconstructing job satisfaction: Separating evaluations, beliefs, and affective experiences. Human Resource Management Review, 12, 1-22.

\section{ABSTRACTS}

This study investigates the impact of social economics on job satisfaction. According to the hypothesis, the adoption of social economics' goals and modes of work organization is a source of job satisfaction: reduction in the separation between conception and execution, increase in work's interest and perceived usefulness, and better cohesion and coordination among workers. Semi-structured interviews were conducted with the workers in two consulting firms in sustainable development in France, one a cooperative and the other a private company. The results of the content analysis corroborate the hypothesis. The fact that social economy's principles have positive impacts on job satisfaction in both companies also shows that social economy's positive influence on well-being at work depends less on formal work organization than on the meaning given to work.

Nous étudions les effets de l'économie sociale sur la satisfaction au travail. Selon l'hypothèse, l'adoption des finalités et des modes d'organisation du travail de l'économie sociale est source de satisfaction au travail : réduction de la séparation entre conception et exécution, augmentation de l'intérêt et de l'utilité perçue du travail, meilleure cohésion et coordination entre les travailleurs. Les résultats de l'analyse de contenu des entretiens semi-directifs menés auprès des salariés de deux entreprises exerçant dans le secteur du conseil en développement durable en France, l'une société coopérative (SCOP) et l'autre entreprise privée, confirment cette hypothèse. Le fait que les principes d'économie sociale ont des conséquences positives sur la satisfaction au travail dans les deux entreprises montre par ailleurs que l'influence positive de l'économie sociale sur le bien-être au travail dépend moins des modes de structuration formels que du sens donné au travail.

Este artículo estudia los efectos de la economía social sobre la satisfacción en el trabajo. Según la hipótesis, la adopción de los objetivos y los modos de organización laboral de la economía social es una fuente de satisfacción en el trabajo : reducción de la brecha entre la concepción y la ejecución, aumento del interés y de la percepción de utilidad del trabajo, mejora de la cohesión y la coordinación entre los trabajadores. Se realizaron entrevistas semi-dirigidas a asalariados de dos empresas consultoras en desarrollo sostenible en Francia, la primera una sociedad cooperativa (SCOP) y la otra una empresa privada, los resultados del análisis del contenido de estas entrevistas confirman la hipótesis.

El hecho de que los principios de economía social tuvieron un impacto positivo sobre la satisfacción en el trabajo dentro de las dos empresas muestra, además, que la influencia positiva de la economía social sobre el bienestar en el trabajo depende menos de la forma organización en trabajo que del sentido dado al mismo. 


\section{INDEX}

Mots-clés: satisfaction au travail, économie sociale, coopérative, sens du travail, organisation du travail

Keywords: job satisfaction, social economy, cooperative, work purposes, work organization Palabras claves: satisfacción en el trabajo, economía social, cooperativa, sentido del trabajo, organización laboral

\section{AUTHORS}

\section{DAVY CASTEL}

davy.castel@univ-lille3.fr, Univ Lille Nord de France, F-59000 Lille, France, UDL3, PSITEC, F-59653 Villeneuve d'Ascq, France

\section{CLAUDE LEMOINE}

claude.lemoine@univ-lille3.fr, Univ Picardie Jules Verne, LPA, F-80025 Amiens, France

\section{ANNICK DURAND-DELVIGNE}

annick.durand-delvigne@univ-lille3.fr, PSITEC - E.A. 4072, Univ Lille Nord de France, F-59000

Lille, France, UDL3, PSITEC, F-59653 Villeneuve d'Ascq, France 